\title{
ALCOREXIA - PSYCHOSOCIAL DETERMINANTS OF THE EATING DISORDER
}

\author{
B. Hoffmann* \\ Institute of Applied Social Sciences, University of Warsaw, Poland
}

\begin{abstract}
Although alcorexia has not yet been formally classified as a disease entity, it is a serious, complex health problem. Alcorexia belongs to behavioral eating disorders and consists in restricting the amount of food intake in order to increase the ability of drinking alcohol without fear of gaining weight. As far as so called traditional eating disorders are usually motivated by a latent desire to be lean and control your body, alcorexia appears to be motivated by the desire to drink large amounts of alcohol along with the desire to be slim.

As the disorder is progressing, the situation may change, both in the direction of anorexia as well as addiction to alcohol. For the purposes of this article, I use the term "alcorexia," but it should be added that the term is used interchangeably with such terms as drunkorexia, alcoholic anorexia, or alcoholic bulimia.
\end{abstract}

Key words: alcorexia, drunkorexia, eating disorder, behavioral disorder, alcohol, body.

Although eating disorders as a health problem have been talked about for many years, this phenomenon raises many questions until now, and definition and diagnostic difficulties occupy a leading place among them. After many years of discussions on the proper classification of eating disorders (1), it was found that they were based on significant changes in self-perception, pursuing unrealistic goals regarding one's own appearance, imposing a strict diet and changes in the functioning of appetite control centers. All these, together with other observations and studies allowed classifying eating disorders as mental disorders, which complications can have a significant impact on the functioning of the whole organism.

A similar situation occurs in the case of alcorexia. The term alcorexia was first used in medical language in 2008, and although it has not yet been formally classified as a complex eating disorder, it can be said that alcorexia is a serious and still threatening health problem (2).

\footnotetext{
*Correspondence to: $\operatorname{Dr}$ hab. Beata Hoffmann, Institute of Applied Social Sciences, University of Warsaw, Poland, hoffmann.beata@gmail.com
}

Alcorexia involves the limitation of the amount of consumed food so that one can drink more alcohol without the concern about gaining weight. Sometimes there are also used weight loss aids: laxatives and diuretics. This tactic is colloquially called the "liquid diet" and is about "saving" calories so that they can be "used" for alcohol drinking (3). Thus, alcorexia is essentially a disorder involving two dysfunctional areas: excessive alcohol consumption and disturbed food-related behavior.

Although alcorexia can be associated with anorexia, it is definitely less than anorexia, bulimia, or orthorexia. So how can one distinguish anorexia from alcorexia? Straightforwardly you can put it this way: a person suffering from anorexia has a disturbed image of their own body, perceives themselves as an obese person and by reducing food intake, reduces their weight on and on. People suffering from alcorexia reduce food intake not to gain weight and to be able to drink alcohol without pangs of conscience that they will gain weight. Alcorectics, unlike anorexics, rarely take action to reduce weight as the aim "in itself". Such behaviors occur before alcohol 
consumption. Of course, as the disorder progresses, the situation may change, both in the direction of anorexia as well as addiction to alcohol.

Some concepts even say that alcorexia is an eating disorder combined with alcohol addiction (4). Here, however, it is important to determine whether eating disorders and weight loss are the consequences of existing alcoholism, or whether, as is in the case of alcorexia, limitation of food consumption results from a desire to drink alcohol without a threat of gaining weight. As far as so-called traditional eating disorders are usually motivated by latent desire to be lean and control someone's body, alcorexia seems to be motivated by the desire to drink large amounts of alcohol along with the desire to be slim.

Coexisting eating disorders and alcohol abuse have been reported in many scientific studies (5). The CASA report published in 2001 presented data showing that $12-18 \%$ of people suffering from anorexia and $30-50 \%$ of people suffering from bulimia were abusing or addicted to alcohol (6). According to research published in the Journal of Studies on Alcohol and Drugs (8/2013), a gene that predisposes to alcohol dependence, in turn, increases the risk of developing bulimia by 38 to $53 \%$ (7).

\section{Alcorectic means who?}

Research on the risk factors contributing to falling into alcorexia has been conducted for a short time. So far, it was focused on the analysis of demographic variables that could indicate some dependencies. As a result of the research, two main tracks were identified.

One of them indicates that alcorexia affects more often women, which, according to researchers, reflects women's tendency to consume alcohol more often and in larger amounts (8), especially by university students in Anglo-Saxon countries, where almost $60 \%$ of girls report alcohol abuse (9).

Alissa Knight's research, conducted among Australian female students, also confirms that behaviors characteristic for alcorexia are almost common. These behaviors usually come down to regular skipping of meals before the event where alcohol is drunk (37.5\%), consuming low-calorie or sugar-free alcoholic beverages during that event $(46.3 \%)$ and performing intense physical exercises just before the event or (less often) sometime after its end (51.2\%) (10).

Knight draws attention to the particular toxicity of alcohol regularly consumed both on empty stomach and after a series of exercises. This increases, according to the researcher, "the risk of serious physical and psychological health consequences, including brain and heart damage, memory loss, loss of consciousness, depression and cognitive deficits" (11). Additionally, differences in alcohol metabolism at men and women cause that women are vulnerable to its detrimental influence more than men.

The results of Pauline Anderson's research also reveal that alcorexia is a new trend persisting particularly among the Canadian student community and, like in Knight's research, this tendency is more common among female students (12). According to the research of the mentioned authors, the fact that the problem affects young women more often than men may be due to the fact that women pay more attention to their body weight and, consequently, the caloric content of meals. For this purpose, they limit their menu and apply starvation diet to maintain the desired calorie balance when consuming alcohol. This phenomenon requires attention, thus I will come back to it later.

The second of the aforementioned tracks concerns the dissemination of alcorexia among both sexes. Although it was initially considered that the problem was primarily affecting women, studies show that men are increasingly inclined to engage in typical alcorexia behaviors. Dr. Dipali V. Rinker from the University of Houston in Texas, explains this by the fact that men tend to consume more alcohol than women, and also become increasingly aware and involved in their body image. Aestheticization is spreading widely, including more and more men who have already awaited "their" illness with a cultural background analogous to appetite disorders (anorexia and bulimia). It is a set of bodily practices defined by the term athletica nervosa, which mainly comes down to compulsive, leading to even extreme fatigue, physical exercises subordinated to body sculpting, while the motivation to take these actions are contents and rich iconosphere entered in men's lifestyle magazines (13). 
According to Rinker, male students can easier adopt bad eating habits associated with alcorexia, because by definition they attach less importance to regular nutrition than female students (14).

At the beginning of 2016, the Research Society on Alcoholism published preliminary results of medical examination of 1,184 students at the University of Houston, which showed that among over-drinkers (more than four drinks for women and more than five for men during a day), up to eight out of ten people were involved in at least one alcorectic behavior at least once per month (15). The study also confirmed that more often such behaviors were showed by students of both sexes living at university campuses than by those living outside of such campuses.

So far the most extensive study of alcorexia carried out by Professor Adam Barry of the University of Florida, on a sample of 22,000 students from forty universities in the United States, confirmed the particular importance of university campuses as places initiating the development of this disorder (16).

\section{Conditions}

It is believed that three factors can affect the development of alcorexia: biological, psychological, and cultural-and-social. Among biological conditions the most often are mentioned, as in the case of other eating disorders, genetic predispositions (17), racial predispositions (18), and those related to the performance of neurotransmitters, especially serotonin, in the neurological system of specific individuals (19). Among psychological conditions, there is the most commonly mentioned tendency to depression (20), anxiety disorders, personality disorders as well as obsessive-compulsive personalities (21). Low self-esteem, a tendency to low mood as well as a feeling of the external location of control, play an important role (22). Attention is also drawn to the deficit of the ability of coping with stress, disturbed self-image, including body image, strong, unmet need for achievements or tendency to dysmorphophobia.

At this point I would like to draw attention to the socio-cultural conditions of alcorexia, which seem to be particularly important. These conditions include primarily two groups of factors. One is related to family determinants of addiction, the other includes social factors inherent in a wider environment of the individual, as well as in the culture in which the individual lives.

According to some researchers, alcorectics come from dysfunctional families dominated by defective behavioral patterns. Factors triggering appearance of the disorder include critical remarks about look and fatness, coming from the nearest environment, as well as family factors, enhancing abnormal eating behavior. Not without the significance is the process of "alcoholic socialization" in a family: model of alcohol consumption and purpose of its consumption.

Factors related to the wider environment of individual as well as cultural conditions seem to play no less important role. According to the cited A. Knight, alcorexia enables fulfillment of two of the most significant social behaviors for young adults: drinking alcohol and having a slim figure (23).

The ideal of a slim figure is not the invention of the present times, but in recent years a body has become the extremely strong means of expressing identity, the cultural requirement through the prism of which people perceive themselves and the others (24).

Making and maintaining low body weight become for many people one of the most important elements of life. According to the promoted canons, an attractive or above all slim body is the condition of success in every area of life.

Such belief is particularly strengthened among girls and very young women. "For young people, mass culture is a kind of a "well "from which they can draw all kinds of patterns, and since the cult of the body is so widely promoted by media, they adopt it into their system of values and create their own identity on a basis of it. They subordinate themselves to cultural and media messages, assigning excessive value to the ideal of a beautiful, slim body, which is identified with attractiveness, happiness, the key to success and prosperity, and more and more often with the ability to control their own lives" (25). In order to conform to the ideal of female beauty, disseminated in the mass media, they are ready to do almost anything (26), including sacrificing their own health. 
The income of companies promoting and offering various forms of weight loss is worth about USD 60 billion in the United States and is growing. Similar trends are also found in European countries and Australia.

At this point, however, it should be noted that in the case of alcorexia, the problems are intensified, because one person has two disorders in parallel that lead to destructive effects: in addition to eating disorders, the excessive drinking of alcohol.

David Jernigan, director of the Center on Alcohol Marketing and Youth at Johns Hopkins Bloomberg School of Public Health, emphasizes that recently the alcohol industry has been increasingly targeting young customers who pay attention to their looks more strongly than older generations. This particularly refers to young women (27).

Changes taking place on the alcohol market, and more specifically the perception of female consumers, have been strengthened by new marketing measures aimed at showing that drinking alcohol does not have to be the equivalent of gaining weight. As Jernigan explains, there are two separate (though sometimes related to each other) trends in alcohol advertising. One of them is located in the so-called "health-promoting" campaigns, such as the Amstel Light advertisement with a sexy, athletic, sweaty young blonde and the slogan "Tell them that you hired a personal trainer from the Netherlands" or Michelob Ultra presenting himself as a "fitness beer" with a man and a woman practicing jogging and the slogan: "95 Cals, 2.6 g carbohydrates, a great choice." In both cases, beer cans are slender and tall, which is supposed to refer to a slender figure that will not be threatened by drinking the mentioned beer. Another category is an alcohol dietary advertising, addressed mainly to young women, which promises all the benefits of drinking without any unwanted weight gain (28). Of course, there are many more examples, just to mention that the international brewery group with headquarters in Leuven, Belgium Anheuser-Busch, which advertises its Select 55 beer directly on the Weight Watchers website, assuming that since bear has only 55 calories, it may well suit the Weight Watchers plan.

Due to the fact that alcorexia prevails among students, it should be taken into account no less important situational factor. It is associated with a change in the current style of learning, entering into a new peer group - the academic community, leaving a family home, and thus - less parental control and greater freedom of decision-making (29). Most researchers believe that this problem is particularly common at the first year of studies. Research of S. C. Burke, J. Cremeens, K. VailSmith and C. Woolsey has shown that $14 \%$ of students in their first year of studies deliberately reduced their intake of calories before a pre-planned evening event combined with alcohol consumption. In contrast, 6\% admitted that the restriction of the amount of calories was associated with á desire to avoid weight gain (30). Of course, the problem does not disappear along with graduation to the next year of studies; it happens that it even gets worse.

Alcorexia is a phenomenon difficult to estimate. Most studies refer to students environments, which do not mean that students are the only victims of this disorder.

\section{Effects of alcorexia}

The same problems that arise in the case of alcohol abuse as well as in the course of anorexia may constitute complications of alcorexia. Like other eating disorders, alcorexia has also very serious health consequences. Such consequences include physical ailments, as well as psychological and social problems closely related to each other. There are complications from the digestive, cardiovascular, endocrine systems, especially problems with blood glucose, risk of dehydration and malnutrition, deficiencies of vitamins (especially from B group) and electrolytes.

Many alcorectics do not admit their ailments, often without realizing their problem. Sometimes, they seek medical help because of complications caused by drinking alcohol on so-called empty stomach or because of other body dysfunctions.

One of the most serious effects of alcorexia is the development of addiction to alcohol with all its consequences.

\section{Help and prevention}

The treatment of alcorexia is multidimensional and includes the treatment of eating disorders and dependence on alcohol (31). Sometimes 
additional pharmacological treatment is needed.

As well as in the case of other addictions, prevention seems to be important. To reduce disorder's dissemination, the action is required on many levels e.g. information campaigns among young people and young adults, with particular emphasis on students, and among medical staff (32). It is certainly necessary to educate and sensitize doctors, including family doctors, to the existing problem, to changing eating habits, especially in combination with consumption of alcohol. No less important is sensitizing loved ones and all those people among which an alcorectic lives. Promoting reasonable nutrition education seems to be as important factor in the prevention of alcorexia as alcohol prevention. The relevant normative regulations should be directed to alcohol industry and the marketing sphere dealing with alcohol products advertising.

\section{CONCLUSION}

Eating disorders are a complex problem; as a clinical unit, they are "incorporated" into the contemporary Western culture. Although alcorexia has not yet been formally classified as a disease, it can be undoubtedly said that it is a serious and still threatening health problem.

As Wojciech Kostowski notes, numerous concepts and hypotheses try to explain the nature of addictions and their mechanisms from different points of view (33). In the case of alcorexia, many questions remain unanswered because, compared to other eating disorders, this problem has been far less studied.

\section{REFERENCES}

1. Żechowski C., Zaburzenia odżywiania się problem współczesnej młodzieży [Eating disorder - a problem of contemporary youth], publikacja ORE Ośrodek Rozwoju Edukacji, www.ore.edu.pl

2. Hall L., Drunkorexia' Deadly New Trend On College Campuses https://newyork.cbslocal.com/2016/08/24/d runkorexia-college-campuses/

3. Hall L., op. cit.

4. Jaworski M., Drunkoreksja - zaburzenie odżywiania połączone $\mathrm{z}$ alkoholizmem wśród młodych dorosłych [Drunkorexia eating disorder combined with alcoholism among young adults], Forum Medycyny Rodzinnej 2014, 8 (5), p. 217-225.
5. Burke S., Wail-Smith K., Matthews J.C., Woolsey C.L., Drunkorexia: Calorie restriction prior to alcohol consumption among college freshman, in Journal of alcohol and drug education 54(2), August 2010, p. 17-34.

6. Burke S., Wail-Smith K., Matthews J.C., Woolsey C.L., op. cit.

7. Tarter R.E., Alterman A.I., Edwards K.L.,Vulnerability to alcoholism in men: a behavior-genetic perspective, Journal of Studies on Alcohol, 46(4), 1985, p. 329356.

8. Based on: Wandler K., Drunkorexia: When Eating Disorders and Substance Abuse Collide, Medical Director Remuda Ranch, Farley Center at Williamsburg Place September 26, 2014 Williamsburg, VA.

9. Drunkorexia: Over half of female university students offset calories from alcohol by skipping meals, study finds, Independent, Thursday 30 June 2016.

10.Knight A., Castelnuovo G., Pietrabissa G., Manzoni G.M., Simpson S., Drunkorexia: An Empirical Investigation among Australian Female University Students, https://moh-

it.pure.elsevier.com/en/publications/drunko rexia-an-empirical-investigation-amongaustralian-female-un, access: 05.07.2018.

11. White A., What happened? Alcohol, memory blackouts, and the brain, National Institute on Alcohol Abuse and Alcoholism, https://pubs.niaaa.nih.gov/publications/arh2 7-2/186-196.htm, access: 11.06.2018.

12.Anderson P., Drunkorexia: New Trend Sweeping College Campuses https://www.medscape.com/viewarticle/865 488, access: 02.07.2018.

13.Śliz A., Czerner A., Jakość życia pacjentów po zabiegach implantoprotetycznych [Quality of life of patients after implant prosthetic treatment], in: (ed.) M.S. Szczepański, B. Pawlica, A. Śliz, A. Zarębska-Mazan, Ciało spieniężone? Szkice antropologiczne i socjologiczne [Cashed body? Anthropological and sociological sketches], Śląskie Wydawnictwa naukowe, Tychy - Opole, 2008.

14.Anderson P., op. cit.

15.Drunkorexia 101: Increasing Alcohol's Effects Through Diet and Exercise Behaviors, Research Society on Alcoholism, June 27, 2016. https://www.sciencedaily.com/releases/201 
6/06/160627100223.htm, access: 12.07.2018

16.Barry A.E., Piazza-Gardner A.K., Drunkorexia: Understanding the Cooccurrence of Alcohol Consumption and Eating/Exercise Weight Management Behaviors, Journal of American College Health, Volume 60, 2012, Issue 3, p. 236243

17. Ranson K., McGue M., Iacono, W., Disordered eating and substance use in an epidemiological sample: II. Associations within families, w: Psychology of Addictive Behaviors, 17(3), 2003, p. 193-202.

18.Goeree M.S., Ham J.C., Iorio D., Race, Social Class, and Bulimia Nervosa, Discussion Paper No. 5823, Institute for the Study of Labor (IZA) in Bonn, June 2011; http://www.econstor.eu/bitstream/10419/52 027/1/669614920.pdf , access: 28.03.2014.

19.Goldbloom D.S., Hicks L., Garfinkel P.E., Platelet serotonin uptake in bulimia nervosa, Bioloaical Psvchiatry, Volume 28, Issue 7, 1 October 1990, p. 644-647.

20.Jacobi C., Hayward C., de Zwaan M., Kraemer H. C., Agras W. S., Coming to terms with risk factors for eating disorders: Application of risk terminology and suggestions for a general taxonomy, Psychological Bulletin, 130(1), 2004, p. 1965.

21.Jacobi C., Hayward C., de Zwaan M., Kraemer H. C., Agras W. S., op. cit.

22.Jacobi C., Hayward C., de Zwaan M., Kraemer H. C., Agras W. S., op. cit.
23.Knight A., Castelnuovo G., Pietrabissa G., Manzoni G.M., Simpson S., op. cit.

24.Owsiejczyk A., Determinanty kulturowe zaburzeń odzywiania. Wizerunki ról rodzinnych [Cultural determinants of eating disorders. Images of family roles], Roczniki Socjologii Rodziny XVIII, UAM 2007.

25.Kaźmierczak N., Kiełbasa S., Patryn R., Niedzielski A., Zachowania anorektyczne wśród społeczności pro-ana [Anorexic behavior among the pro-ana community] Medycyna Ogólna i Nauki o Zdrowiu, Tom 21, Nr 2, 2015, p. 168-173.

26. Owsiejczyk A., op. cit.

27. Urist J., Road to 'Drunkorexia', The Atlantic, $27 \quad$ Mar. 2013 https://www.theatlantic.com/health/archive/ 2013/03/road-to-drunkorexia/274205/, access: 11.07.2018.

28. Urist J., op. cit.

29.Jaworski M., op. cit.

30.Burke S., Wail-Smith K., Matthews J.C., Woolsey C.L., op. cit.

31.Jaworski M., op. cit.

32.Bator E., Bronkowska M., Ślepecki D., Biernat J., Anoreksja - przyczyny, przebieg, leczenie [Anorexia - causes, course, treatment], Nowiny Lekarskie, 2011, 80 (3), p. 184-191.

33. Kostowski W., Podstawowe mechanizmy i teorie uzależnień, [Basic mechanisms and theories of addiction] Alkoholizm i Narkomania [Alcoholism and Drug Addiction], 19(2), 2006, p. 139-168. 